\title{
The Incidence and Risk Factor Analysis of Drug Induced Liver Injury (Dili) in a Surabaya Hospital
}

\author{
Sherly Tandi Arrang ${ }^{1}$, Widyati $^{2}$ \\ ${ }^{1}$ Jurusan Farmasi, Program Studi Farmasi, Universitas Katolik Indonesia Atma Jaya, Jakarta, Indonesia, 14440 \\ ${ }^{2}$ Jurusan Farmasi,Fakultas Farmasi, Universitas Surabaya, Surabaya, Indonesia, 60293
}

\author{
Article Info: \\ Received: 12 Juli 2018 \\ in revised form: 12 Agustus 2018 \\ Accepted: 20 September 2018 \\ Available Online:30 September 2018 \\ Keywords: \\ Drug induced liver injury \\ DILI \\ Risc factor
}

Corresponding Author:

Sherly Tandi Arrang

Jurusan Farmasi, Prodi Farmasi,

Universitas Katolik Indonesia Atma

Jaya, Pluit, 14440, Jakarta,

Indonesia

Mobile : +62852-4174-6788

Email: sherta_222@yahoo.com

\begin{abstract}
The research has been conducted on the incident and analysis of risk factors drug liver injury (DILI) in a Surabaya Hospital. The aim of this study was to determine the incident of DILI, know which drugs cause DILI, and see the association of risk factors to DILI. The research method was descriptive and analytical observational (prospective cohort). Danan-Benichou scale is a tool used to ascertain drugs that cause DILI. Based on data collected for 3 months, the population was 1202 patients. Samples fulfilling the inclusion and exclusion criteria were 310 patients, the risk drug group of DILI were 285 patients (11 DILI, 274 Non-DILI), and the non-risk drug group 25 patients (11 DILI, 14 Non-DILI). The incident of DILI was 3.55\%. Drugs that cause DILI are ranitidine (4 cases), omeprazole (1 case), rifampicin (2 cases), meropenem (1 case), ciprofloxacin (1 case), methotrexate (1 case), and dexamethasone (1 case). Characteristic of patients with DILI (11 patients) are average age of 59.27 \pm 15.54 years (23-73 years), belonging to high risk group $(54.55 \%)$, male gender $(81,82 \%)$, have moderate comorbid disease $(54.55 \%)$, and are not comsumsing alcohol (100\%). This research use logistic regression analysis through SPSS 17.0 program to see the relation of risk factor to DILI incident. The p results were obtained from sex $(0,156)$, age $(0,534)$, and comorbid 79isease $(0,213)>\alpha(0,05)$ which means gender, age, and comorbid disease do not significantly affect the incident of DILI.
\end{abstract}

Copyright (C) 2017 JFG-UNTAD This open access article is distributed under a Creative Commons Attribution (CC-BY-NC-SA) 4.0 International license.

How to cite (APA 6th Style):

Arrang, S.T., Widyati. (2018). The Incidence and Risk Factor Analysis of Drug Induced Liver Injury (DILI) in a Surabaya Hospital. Jurnal Farmasi Galenika : Galenika Journal of Pharmacy, 4(2), 79-86. doi:10.22487/j24428744.2017.v4.i2.10459 


\begin{abstract}
ABSTRAK
Telah dilakukan penelitian terhadap angka kejadian dan analisis faktor risiko kerusakan hati yang disebabkan oleh obat (DILI) di sebuah Rumah Sakit Surabaya. Tujuan dari penelitian untuk mengetahui frekuensi kejadian DILI, obat-obat apa yang menyebabkan DILI dan melihat hubungan faktor risiko terhadap DILI. Metode penelitian adalah observasional deskriptif dan analitik (prospective cohort). Danan-Benichou scale merupakan alat bantu yang digunakan untuk memastikan obat penyebab kerusakan hati. Berdasarkan dari pengambilan data selama 3 bulan diperoleh populasi sebesar 1202 pasien. Sampel yang memenuhi kriteria inklusi dan eksklusi 310 pasien, kelompok obat berisiko 285 pasien (11 DILI, 274 Non-DILI), dan kelompok obat non-risiko 25 pasien (11 DILI, 14 Non-DILI). Frekuensi kejadian DILI adalah 3,55\%. Obat yang menyebabkan kerusakan hati adalah ranitidine (4 kasus), omeprazole (1 kasus), rifampicin (2 kasus), meropenem (1 kasus), ciprofloxacin (1 kasus), methotrexate (1 kasus), dan dexamethasone (1 kasus). Pasien yang mengalami DILI karena obat berisiko (11 pasien) memiliki rata-rata usia 59,27 $\pm 15,54$ tahun (23-73 tahun), tergolong dalam kelompok risiko tinggi $(54,55 \%)$, jenis kelamin laki-laki $(81,82 \%)$, pasien yang memiliki penyakit penyerta tingkat sedang $(54,55 \%)$, dan tidak memiliki kebiasaan mengkonsumsi alkohol (100\%). Untuk melihat hubungan faktor risiko terhadap kejadian DILI, dilakukan analisis menggunakan analisis regresi logistik melalui program SPSS 17.0, dan hasilnya diperoleh $\mathrm{p}$ dari jenis kelamin $(0,156)$, usia $(0,534)$, dan penyakit penyerta $(0,213)>\alpha(0,05)$, yang artinya jenis kelamin, usia, dan penyakit penyerta tidak signifikan berpengaruh terhadap kejadian DILI.
\end{abstract}

Kata Kunci : Drug induced liver injury, DILI, faktor resiko

\section{INTRODUCTION}

Drug side effects are unexpected effects or unwanted effects, which occur in approproate drug use (Beard, 2001). Drug side effects have major impact on public health and cause economic burdens, that cases can be prevented (Wu et al., 2010; Litaker \& Wilson, 2005). In the United States, drug side effect is the top ten causes of death and spent 30 billion US dollars annually (Anderson \& Borlak, 2011). In the United Kingdom, during period 1999-2008, 557.978 side effects are occured and increased risk of death (Wu et al., 2010).

Drug induced disease is one of drug side effects form (Litaker \& Wilson, 2005). Based on the results of preclinical and clinial trials, drug-induced liver injury (DILI) is the most common type of drug side effect. It is because liver is the metabolic center of drugs and xenobiotis, so liver is susceptible to toxicity (Bagheri et al., 2000; Holt \& Ju, 2006). DILI is also influenced by many factors, such as genetics, age, gender, comorbid disease, alcohol, and nutritional status (Kaplowitz, 2004; MacLaren, 2005).

About 20-30\% of acute liver failure case had $90 \%$ mortality rate, associated with drugs (Ward \& Daly, 2001). In 2003, National Institutes of Health (NIH) established the Drug-Induced Liver Injury Network (DILIN). DILIN is combination of 6 academic medical centers that identify and follow patient with idiosyncratic drug hepatotoxicity, and for the first time collect 300 cases of DILI in the United States. The agents of hepatotoxicity such as antibiotics (46\%) and psychotropic drugs (15\%) (Brett, 2009). About 800 drugs were associated with DILI events and caused hospital admissions 1 in 600 to 3500 events (Ward \& Daly, 2001). Increasing incident of DILI is due to the increasing number of chemical agents or drugs into the worldwide (MacLaren, 2005).

Clinical features of DILI are not specific. The reactions between each drug are different. Some are predictable and some are unpredictable. Unpredictable or idiosyncratic reactions often occur, and the rate is very high. These unpredictable events can be assessed and monitored through patient's history and laboratory results, such as Alanine Aminotranferase (ALT), Aspartate Aminotransferase (AST), Alkaline Phosphatase (ALP), GammaGlutamyltransferase (GGT), 5'- Nucleotidase, Lactate Dehydrogenase (LDH), Total Bilirubin, Conjugated Bilirubin, and Unconjugated Bilirubin (Kaplowitz, 2004; Kirchain \& Rondal, 2008; Wells, Dipiro, Schwinghammer, \& Dipiro, 2009). The treatment history of patient is important for detecting DILI events (Wells, Dipiro, Schwinghammer, \& Dipiro, 2009).

The instrument commonly used to assess DILI events is the CIOMS / RUCAM scale (Council for International Organizations of Medical 
Sciences/Roussel Uclaf Causality Assessment Method). The CIOMS / RUCAM scale was proposed by Danan-Benichou at The International Consensus Meeting in the 1990s. Although the the CIOMS/RUCAM scale widely used in evaluating DILI, the criteria are very complex (Bagheri et al., 2000; Lozano-lanagrán, Robles, Lucena, \& Andrade, 2011; Danan \& Benichou, 1993; Andrade et al., 2007; Wai, 2006). Therefore, in this study we used a simple scale measurementthat is Danan-Benichou scale (Wells, Dipiro, Schwinghammer, \& Dipiro, 2009).

The research about incident of DILI in Indonesia is still less. For that purpose, this study was conducted to look how many DILI incident occurred in Indonesia.

\section{MATERIAL AND METHODS}

\section{Sample}

This study population was inpatient in a Surabaya hospital. The study sample was study population with inclusion and exclusion criteria, which agreed to participate in this study. The samples collected was classified into 2 groups, the risk drug group and the non-risk drug group. Each of these groups was divided into 2 small groups, liver damage (DILI)group and non-DILI groups. The sampling of this quantitative research using the technique of nonprobability sampling, consecutive sampling.

\section{Inclusion and Exclusion Criteria}

Inclusion criteria, such as:

a) Patients with age $\geq 18$ years.

b) Inpatient during this study period, with male and female sex that consuming drugs.

c) Patients who have Liver Function Test (LFTs), such as ALT, AST, GGT, etc.

Exclusion criteria, are patients with underlying liver disease, such as cirrhosis, viral hepatitis (A, B, C, D and $\mathrm{E}$ ), autoimmune hepatitis, fatty liver, cancer with metastasis to the liver, DHF (Dengue High Fever), gall bladder obstruction, congestive heart failure (CHF), hypotension, hyperthermia, shock, vascular disease, biliary pancreatic tumors, bacterial sepsis, Salmonella infection, Cytomegalo virus (CMV), and Epstein-Barr virus (EBV).

\section{Research design}

The research is quantitative research, with descriptive and analytic observational (non-experimental) research method.
Descriptive observational research method aims to see the frequency of liver damage events (percentage) induced by drugs and what drugs are dominant to cause liver damage.

Analytic observational research method is prospective cohort study, aims to see the relationship of drugs to DILI events. The research design can be seen in the picture below.



Figure 1. Research Design

\section{Research Instrument}

Danan-Benichou scale is the instrument to assess whether a drug causing liver damage (DILI).

\section{Data analysis}

Quantitative data analysis was analyzed by:

Descriptive as percentage (\%) of all DILI events

$\%$ DILI events

$=\frac{\text { Total of the risk drug group with DILI }}{\text { total sample }} \times 100 \%$

and statistical analysis, by multiple logistic regression method, aims to see the effect of risk factor on DILI.

\section{RESULTS AND DISCUSSION}

\section{Percentage (\%) of DILI and Non-DILI events}

Based on 3 months observations, the population of inpatients was 1202 patients, the sample was 310 patients. The percentage of DILI and Non-DILI incident (\%) can be seen in Table 1 and Figure 2. The incidence of liver damage (DILI) caused by the risk drug was 11 cases $(3.55 \%)$. The incident of DILI is small, but should be monitored and avoided.

$\frac{\text { Table 1. Percentage (\%) Dili and Non-DILI incidents }}{\text { Group }}$

\begin{tabular}{lccc}
\hline The Risk Drug & 11 & 274 & 285 \\
& $(3,55 \%)$ & $(88,39 \%)$ & $(91,94 \%)$ \\
Non-Risk Drug & 11 & 14 & 25 \\
& $(3,55 \%)$ & $(4,51 \%)$ & $(8,06 \%)$ \\
Total & 22 & 288 & 310 \\
& $(7,1 \%)$ & $(92,90 \%)$ & $(100 \%)$ \\
\hline
\end{tabular}




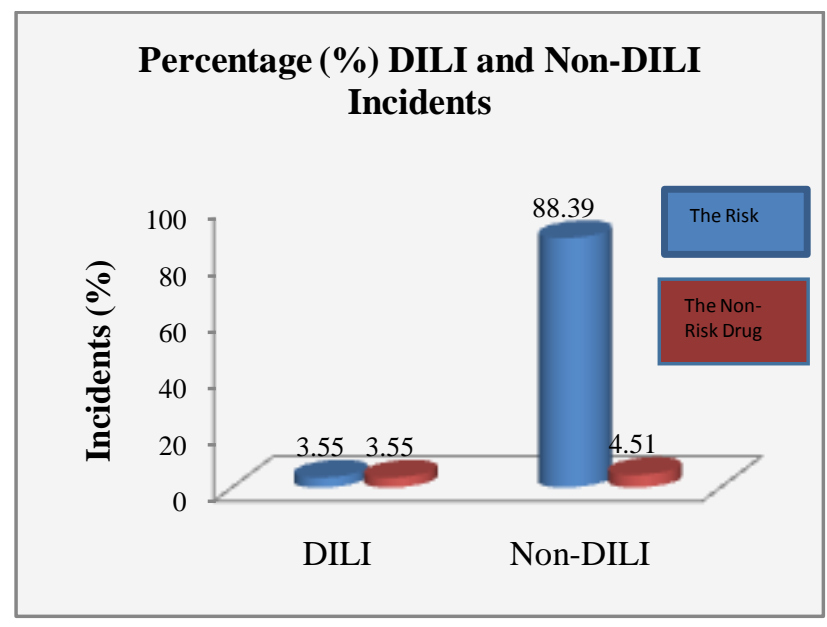

Figure 2. Graphs of DILI and Non-DILI Incidents

Drug-induced hepatotoxicity is $3-10 \%$ of all side effects (Ward \& Daly, 2001). Another literature said $7 \%$ of reported cases (Saukkonen et al., 2006). A French cohort study found that DILI incident occurred in 14 cases of 100,000 patients. Meanwhile, research in Spain, for approximately 10 years (since 1990), occurred 461 cases of DILI. Research in Sweden from 1995-2005 reported 77 cases of DILI of 1164 patients $(6.6 \%)$ (Andrade et al., 2007; Polson, 2007). Research in the UK reported 0.7 to $1.4 \%$ DILI cases (Andrade et al., 2007). A prospective study in Singapore for 1 year (2003-2004), reported 29 DILI cases (Lozano-lanagrán, Robles, Lucena, \& Andrade, 2011). Another study conducted in China (retrospectively) for 1 year reported 25 cases of DILI (Xu, Chen, Xu, \& Zhou, 2012).

\section{Risk Drug Causing DILI}

Eleven cases of DILI was found in this study (Fig. 3).There were 8 drugs causing DILI, including ranitidine (3 cases), omeprazole (1 case), methotrexate (1 case), meropenem (1 case), rifampicin (2 cases), ciprofloxacin (1 case), ceftriaxone (1 case), and dexamethasone (1 case).

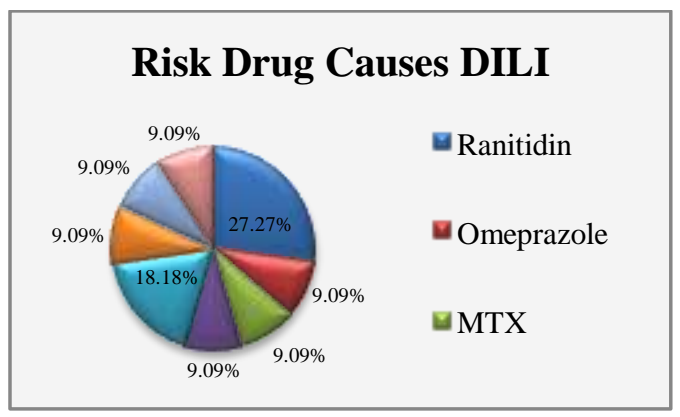

Figure 3. Risk Drug Causes DILI

Each of these drugs can afford different forms of liver damagethat can be seen in the table 2 .

Table 2. Forms of liver damage caused by drugs suspected

\begin{tabular}{lc}
\hline \multicolumn{1}{c}{ Drugs } & Liver Demage Form \\
\hline Ranitidine & Hepatitis \\
Ceftriaxone & Hepatitis \\
Meropenem & Cholestasis \\
Rifampicin & Cholestasis \\
Ciprofloxacin & Cholestasis \\
Omeprazole & Hepatitis-Cholestasis (mixed) \\
Methotrexate & Cholestasis \\
Dexamethasone & Steatosis \\
\hline
\end{tabular}

The eight drugs that cause liver damage are classified in a more specific group of class therapy. There are 4 drugs belonging to the antibiotic group, namely meropenem, ciprofloxacin, ceftriaxone, and rifampicin. According to the literature, the large number of DILI cases resulting from antibiotic usage is $25-45 \%$ of all DILI cases (Colt \& Shapiro, 1989). In this study, DILI cases resulting from antibiotic use (meropenem, ciprofloxacin, ceftriaxone, and rifampicin) were 5 cases $(45.45 \%)$. The second highest frequency was occupied by antisecretory drugs (ranitidine and omeprazole) for 4 cases $(36.36 \%)$, followed by antimetabolite (methotrexate) of 1 case $(9.09 \%)$, and glucocorticoid (dexamethasone) of 1 case $(9.09 \%)$. Antibiotics are the most common cause of DILI in this study. These results are similar in the United States, Europe, Japan and China, but are different from some Asian countries.

A prospective study in the United States (5 locations) reported that drugs causing liver damage are antibiotics group (46\%), followed by psychotropic drugs (15\%), herbs (9\%), immunomodulators (5.5\%), analgesics (5\%), antihypertensives (5\%), endocrine agents (4\%), and lipid-lowering agents (3.4\%). Two other studies conducted in Europe reporting antibiotics, lipid-lowering agents, antidepressants, and analgesics are the main causes of DILI (Andrade et al., 2007). It was reported from a study in Spain, $39 \%$ DILI cases occurred by antibiotics, $15 \%$ of central nervous system agents, $11 \%$ of analgesics and $5 \%$ of lipid-lowering agents (Lozano-lanagrán, Robles, Lucena, \& Andrade, 2011; Andrade et al., 2007). A study in Switzerland (784 patients) mentioned that the main agents causing DILI were antibiotics (27\%), analgesics (5\%), dilsufiram 
$(3.4 \%)$, carbamazepine $(2.2 \%)$, and lipid-lowering agents $(1 \%)$. The result of retrospective studies in Japan (multicenter), the drugs that caused DILI were antibiotics (14\%), then central nervous system drugs $(10 \%)$, dietary supplements $(10 \%)$, analgesics $(9.9$ $\%)$, and Chinese herbs $(7.1 \%)$ (Lozano-lanagrán, Robles, Lucena, \& Andrade, 2011). Retrospective studies in China for 12 months (January-December 2012), the drugs that cause DILI were antibiotics (32\%) and glucocorticoids (24\%) (Xu, Chen, Xu, \& Zhou, 2012). However, different results were reported in Korea and Singapore. The prospective study in Korea reported the percentage of DILI incident due to herbs was $27.5 \%$, drugs $20.8 \%$, and dietary supplements $13.7 \%$. For prospective study in Singapore of 29 DILI cases, traditional Chinese medicines (TCM) were the main cause of DILI incident $(52 \%)$, followed by antituberculous drugs (24\%) (Lozano-lanagrán, Robles, Lucena, \& Andrade, 2011; Andrade et al., 2007). From these research reports, it can be concluded that antibiotics are the biggest cause of DILI in America, Europe, Japan and China, while for some Asian countries, TCM is the main cause of DILI incident.

The assessment result through the Danan-Benichou scale instrument, risk value of each drug is 6-8. The meaning of the value is probable $(50 \%-74 \%)$, that means there is considerable evidence and supports of the relationship between drug and DILI event. The results of the assessment are calculated without rechallenge assessment. If the rechallenge is performed, the likelihood of the assessment results may increase.

\section{Risk Factors of DILI incident}

Risk factors that may increase the risk of DILI are age, sex, genetics, duration of drug use, drug interactions, nutritional status, comorbid disease, and alcohol (Figure 4) (Maddrey, 2005; Sierra \& Torres, 2004). Risk factors in this study were confounding variables, including age, gender, nutritional status, comorbid disease, and alcohol.

The risk factor of this research can be seen in table 3 . The samples collected during the study (310 patients) are average of $57.94 \pm 16.47$ years (18-90 years), male sex $(59.68 \%)$, all patients did not comsume alcohol (100\%), and the patient did not have comorbid disease $(41.61 \%)$. Nutritional status data in this study could not be collected for all samples, due to the limited available data related to nutritional status. Therefore, nutritional status data can not be presented and processed

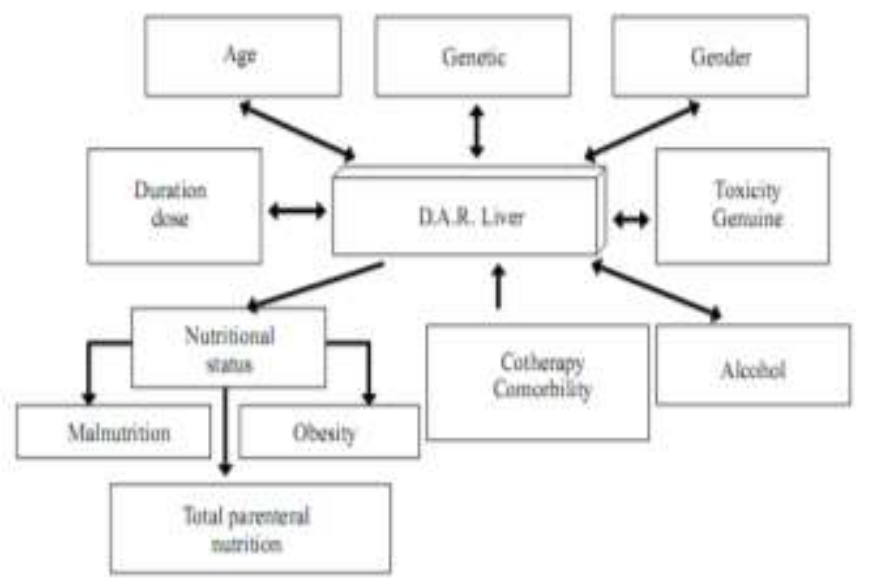

Figure 4. Risk Factors of DILI (Sierra \& Torres, 2004)

Table 3. Data on risk factors for dili causes of overall sample research

\begin{tabular}{lcc}
\hline \multicolumn{2}{c}{ Risk Factor } & Total Sample(\%) \\
\hline Age & $\begin{array}{c}\text { Low Risk } \\
\text { (<65 years) }\end{array}$ & $176(56,77 \%)$ \\
& High Risk & $134(43,23 \%)$ \\
& $\begin{array}{l}(\geq 65 \text { years) } \\
\text { Average } \pm \text { SD }\end{array}$ & $57,94 \pm 16,47$ \\
& & $(18-90$ years) \\
Gender & Male & $185(59,68 \%)$ \\
& Famale & $125(40,32 \%)$ \\
Comorbid & 0 & $129(41,61 \%)$ \\
disease & 1 & $87(28,06 \%)$ \\
& 2 & $69(22,26 \%)$ \\
& 3 & $25(8,06 \%)$ \\
Alcohol & 4 & 0 \\
& 5 & 0 \\
& Yes & 0 \\
& No & $310(100 \%)$ \\
\hline
\end{tabular}

Patients with DILI (11 cases) had an average age of $59.27 \pm 15.54$ years (23-73 years), high-risk age group $(54.55 \%)$, male gender $(81.82 \%)$, patients who had 2 comorbid disease $(45.45 \%)$, and did not have a habit of consuming alcohol (100\%).

Comorbid disease in this study include Diabetes Mellitus (DM), Hypertension, HIV, Rheumatoid Arthritis (RA) or Osteoarthritis (OA), and Chronic Kidney Disease (CKD). Patient with DILI in this study had 2 comorbid disease. Most of the patients in this study had DM. Complications of type 2 diabetes is liver disorder and associated with hepatobiliary disease, including non-alcoholic fatty liver disease, cirrhosis, acute liver failure, hepatocellular carcinoma, and cholelithiasis. The risk of liver damage due to methotrexate can be increased in DM patients (Ward \& Daly, 2001; North-Lewis, 2008; 
Kaplowitz, 2007; Aithal, 2011; Metha, 2012). ALP increases also occur in patients with pulmonary infection (Fischbach \& Dunning, 2009). In CKD patients, metabolites or substances that should be excreted through the kidneys, will reenter to the bloodstream, and consequently organs demage, including liver (North-Lewis, 2008).

In this study, DILI occured at high risk age $(\geq 65$ years), whereas Non-DILI was higher in low-risk patients $(<65$ years). Side effects occur in elderly patients is greater than young adults or children. Elderly patients decreased organ function, resulting in pharmacodynamic and pharmacokinetics changes from drugs (Ward \& Daly, 2001; North-Lewis, 2008; Deleve, 2007; Kimmoun \& Samuel, 2002). Drug interactions also occur in elderly patients. Decreased clearance of drug metabolites, drug bonds, hepatic blood flow, hepatic volume, and drug distributionwill affordingincreased plasma drug levels. Therefore, the risk of hepatotoxicity increases. Elderly patients usually have infections as well, less nutritional status, and multiple diseases. These may increase the risk of hepatotoxicity (Tostmann et al., 2008; Metha, 2012). A study had been reported that the greater incident of hepatotoxicity at age $>35$ years than age $<35$ years (Saukkonen et al., 2006). Other literature reported DILI generally occur at age $>50$ or 60 years, but not all studies showed similar results (Polson, 2007).

From this study, DILI incidents were greater in men than in women. This may be due to the proportion of male and female samplesare not balance. The number of male patients was more than women. Women were more likely to take drugs.Their CYP3A enzyme activity was also greater than men, so women more often experienced DILI (1,5 times) than men (Ward \& Daly, 2001; Tostmann et al., 2008; Deleve, 2007; Polson, 2007; Metha, 2012). Most studies have reported an increase in hepatotoxicity occurring in women, but not always in all drugs and all studies, even the results are not necessarily significant. Several cases reported DILI incident between men and women were more or less equal, and sometimes DILI incident was greater in males. A recent study in Sweden about risk factors and DILI incident, the results did not show differences of DILI incident between men and women (Saukkonen et al., 2006; Polson, 2007). Other studies have reported that women have hepatotoxicity four times more than men. Two other studies showed no increased risk of liver damage in women (Saukkonen et al., 2006).

All patients in this study, both DILI and non-DILI events did not consume alcohol. If the patient consumes alcohol, the risk of DILI increases. The long-term use of alcohol induces the cytochrome P450 isoenzyme. It has potential to cause drug toxicity, such as methotrexate (Ward \& Daly, 2001; North-Lewis, 2008; Tostmann et al., 2008; Deleve, 2007; Aithal, 2011). Two mechanisms of alcohol cause hepatotoxicity. Firstly, cythochrome P450 induced that increase the drugs metabolite. Secondly, it decreases liver gluthation that is necessary for the detoxification process of compounds (Kimmoun \& Samuel, 2002).

The influence of risk factor (confounding variable) to DILI event (dependent variable) was analyzed using logistic regression (multivariate analysis) through SPSS program version 17.0. The result of $p$ value of sex $(0,157)$, age $(0,627)$, and comorbid disease $(0,137)>\alpha(0,05)$, which mean gender, age, and comorbid disease did not significantly influence the DILI incident (Table 4).

Table 4. Relationship confounding variables to dependent variables

\begin{tabular}{lc}
\hline \multicolumn{1}{c}{ Risk Factors } & $p$ (sig.) \\
\hline Gender & 0,157 \\
Age & 0,627 \\
Comorbid disease & 0,137 \\
\hline
\end{tabular}

The influence of risk factor on DILI incident, can be seen from Negelkerke R Square value, that is $6.8 \%$. DILI incident is affected by risk factor of $6.8 \%$.

\section{CONCLUSION}

The percentage of DILI incident in a Surabaya Hospital for 3 months was $3.55 \%$. Drugs that causing DILI are antibiotics of $45,45 \%$ (meropenem 1 case, rifampicin 2 cases, ciprofloxacin 1 case, ceftriaxone 1 case), antisecretory drugs of $36,36 \%$ (ranitidine 3 cases, omeprazole 1 case), antimetabolite of $9,09 \%$ (methotrexate 1 case), and glucocorticoid 9.09\% (dexamethasone 1 case). Risk factors such as age, sex, comorbid disease, and alcohol usage did not significantly affect the incident of DILI.

\section{REFERENCE}

Aithal, G.P. (2011). Hepatotoxicity related to antirheumatic drugs: chronic drugassociated liver disease. Medscape. CME information.

Anderson, N., \& Borlak, J. (2011). Correlation versus Causation? Pharmacovigilance of the Analgesic Flupirtine Exemplifies the Need 
for Refined Spontaneous ADR Reporting. PLoS ONE, 6(10), 1-11.

Andrade, R. J., Robles, M., Fernández-castañer, A., López-ortega, S., López-vega, M. C., Andrade, R. J., ... López-vega, M. C. (2007). Assessment of drug-induced hepatotoxicity in clinical practice: A challenge for gastroenterologists, 13(3), 329-340.

Bagheri, H., Michel, F., Lapeyre-Mestre, M., Lagier, E., Cambus, J. P., Valdiguié, P., \& Montastruc, J. L. (2000). Detection and incidence of drug-induced liver injuries in hospital: a prospective analysis from laboratory signals. J Clin Pharmacol, 50, 479-484.

Beard, K. (2001). Adverse drug reactions (pp. 1-13). London: Pharmaceutical Press.

Brett, A.S. (2009), Drug-induced liver injury in the U.S. Journal Watch General Medicine. https://www.jwatch.org/jw200901080000001 /2009/01/08/drug-induced-liver-injury-us

Colt, H. G., \& Shapiro, A. P. (1989). Drug-Induced Illness as a Cause for Admission to a Community Hospital. J Am Geriatr Soc, 37(4), 323-326.

Danan, G., \& Benichou, C. (1993). Causality assessment of adverse reactions to drugs-i. a novel method based on the conclusions of international consensus meetings: application to drug-induced liver injuries. J. Clin. Epidemiol, 46(11), 1323-1330.

Deleve, L.D. (2007). Drug-induced liver disease (2nd ed.,pp.291-299). New York: Informa Healthcare USA Inc.

Fischbach, F. T., \& Dunning, M. B. (2009). A Manual of Laboratory and Diagnostic Tests (8th ed.). United Kingdom: Lippincott Williams \& Wilkins.

Holt, M. P., \& Ju, C. (2006). Mechanisms of Drug-
Induced Liver Injury. The AAPS Journal, 8(1), E48-E54.

Kaplowitz, N. (2004). Drug-Induced Liver Injury. Clinical Infectious Disease, 38(2), S44-S48.

Kaplowitz, N. (2007). Drug-induced liver disease (2nd ed., pp. 1-10). New York: Informa Healthcare USA Inc.

Kimmoun, E., \& Samuel, D. (2002). Antituberculous drugs in patients with chronic liver disease. Journal of Gastroenterology and Hepatology, 17, S408-S412.

Kirchain, W. R., \& Rondall, E. A. (2008). Pharmacotherapy: A pathophysiologic approach (7th ed., pp. 651-658). New York: The McGraw-Hill Companies.

Litaker, J. R., \& Wilson, J. P. (2005). Drug induced disease (pp. 3-10). Bethesda: American Society of Health-System Pharmacist.

Lozano-lanagrán, M., Robles, M., Lucena, M. I., \& Andrade, R. J. (2011). Hepatotoxicity in 2011 - Advancing resolutely. Rev Esp Enferm Dig, 103, 472-478.

MacLaren, R. (2005). Drug induced disease (pp. 515513). Bethesda: American Society of HealthSystem Pharmacist.

Maddrey, W. C. (2005). Drug-Induced Hepatotoxicity. J Clin Gastroenterol, 39(2), 83-89.

Metha, N. (2012). Drug-induced hepatotoxicity. Medscape Reference.

North-Lewis, P. (2008). Drugs and the liver. United Kingdom: Pharmaceutical Press.

Polson, J. E. (2007). Hepatotoxicity Due to Antibiotics. Clin Liver Dis, 11, 549-561.

Saukkonen, J. J., Cohn, D. L., Jasmer, R. M., Schenker, S., Jereb, J. A., Nolan, C. M., ... Sterling, T. R. (2006). An Official ATS 
Statement: Hepatotoxicity of Antituberculosis Therapy. Am J Respir Crit Care Med, 174, 935-952.

Sierra, F. A., \& Torres, D. P. (2004). A concise and structured review of drug-induced toxic hepatic disease. Annals of Hepatology, 3(1), $18-25$.

Tostmann, A., Boeree, M. J., Aarnoutse, R. E., Lange, W. C. M. De, Ven, A. J. A. M. Van Der, \& Dekhuijzen, R. (2008). Antituberculosis drug-induced hepatotoxicity: Concise up-to-date review. Journal of Gastroenterology and Hepatology, 23, 192-202.

Ward, F., \& Daly, M. (2001). Adverse drug reactions (pp. 73-97). London: Pharmaceutical Press.

Wu, T., Jen, M., Bottle, A., Molokhia, M., Aylin, P., Bell, D., \& Majeed, A. (2010). Ten-year trends in hospital admissions for adverse drug reactions in England 1999 - 2009. $J R$ Soc Med, 103(6), 239-250. https://doi.org/10.1258/jrsm.2010.100113

Xu, H., Chen, Y., Xu, J., \& Zhou, Q. (2012). Druginduced liver injury in hospitalized patients with notably elevated alanine aminotransferase. World J Gastroenterol, 18(41), 5972-5978. 